\title{
Geçici Süreyle Kurum Bakımını Deneyimlemiş Çocuklar: Korunma Altına Alınma Sebepleri ve Deneyimleri
}

\author{
${ }^{a}$ Meliha Funda Afyonoğlu ${ }^{1}$ bNur Feyzal Kesen ${ }^{\mathrm{c}}$ Güle İşler \\ ${ }^{a}$ Dr. Ögrr. Üyesi, Selçuk Üniversitesi, Türkiye \\ ${ }^{b}$ Doç. Dr., Selçuk Üniversitesi, Türkiye \\ ${ }^{c}$ Yüksek Lisans Öğr., Selçuk Üniversitesi, Türkiye
}

$\ddot{O} z$

$\mathrm{Bu}$ araştırma geçici süreyle kurum deneyimi yaşamış 13-18 yaş aralığındaki çocukların korunma altına alınma sebeplerini ve deneyimlerini öğrenmeyi amaçlamaktadır. Araştırma nitel araştırma deseninde ve fenomenolojik yaklaşımla tasarlanmış olup, çocuklara kartopu örnekleme yöntemiyle ulaşılmıştır. Görüşmeler yarı- yapılandırılmış derinlemesine görüşme formu aracılığıyla gerçekleştirilmiş, veriler tematik analiz yöntemiyle analiz edilmiştir. Araştırma bulgularından "bir cezalandırma stratejisi olarak evden kaçış”, "fiziksel şiddet”, “cinsel şiddet ve aile desteğinin önemi” ve "kurum bakımı sonrası aileye geri dönüş” dört temel tema olarak keşfedilmiştir. Aile içi iletişimdeki eksiklikler, ebeveynlerin sınır, kural ve otoriteyi yanlış kullanmasının yanı sıra fiziksel şiddet ve cinsel şiddet çocukların evden kaçmasının temel sebepleri olarak bulunmuştur. Bununla birlikte, evden kaçmayı bir cezalandırma stratejisi olarak kullanan çocukların kurum deneyimlerini pişmanlıkla betimledikleri görülmüştür. İhmal ve istismarın ilk tespit edildiği yerin genellikle okul olması sebebiyle, koruma altına alınma ihtiyacını ortadan kaldırmak için öncelikli olarak okul sosyal hizmetinin yaygınlaştırılması, çocuklarla ve ailelerle çalışmaların gerçekleştirilmesi temel öneriler olmuştur.

Anahtar Kelimeler: korunmaya muhtaç çocuklar, korunmaya ihtiyacı olan çocuklar, çocuk ihmal ve istismar1, sosyal hizmet. 


\section{Temporarily Institutionalized Children: The Reasons for their Protection and Their Experiences}

\section{Extended Summary}

This research aims to learn the reasons and experiences of children between the ages of 13-18 who experienced institutional care temporarily. The research was designed in a qualitative research design and with a phenomenological approach since it aims to learn the lived experience of individuals from themselves and to reveal the implications of the institutional experience. Within the scope of the research ten children were reached by using the snowball sampling method. The interviews were conducted through a semi-structured in-depth interview form, and the data were analyzed using thematic analysis method. "Escape from home as a punishment strategy", "physical violence", "sexual violence and the importance of family support" and "return to the family after institutional care" were established as four basic themes. The first theme named as "escape from home as a punishment strategy" reveals that lack of communication, misuse of borders, rules, and authority as well as physical and sexual violence were found to be the main reasons for children's escape from their homes. Consequently, it is seen that children can use escape from home as a punishment of their parents which leads to their institutionalization. The second theme named as "physical violence" shows that miscommunication in the family and parents' use of violence as a problem-solving strategy is another reason for children's protection. The third theme "sexual violence and the importance of family support" shows that children can hinder sexual violence experiences and when these experiences combined with family problems, it may lead to state protection. It was also observed that when children can take family support they need, they can develop healthy coping mechanisms about their sexual violence experiences. The last theme "return to the family after institutional care" indicates that children especially those who use escape from home as a punishment strategy described their institutional care experience with regret.

Since the first place where neglect and abuse were detected is usually the school, the main suggestions have been to disseminate school social work and to carry out educational activities with children and families to eliminate the need for protection. The study design of these activities for children must include children's rights, family rules, roles, and boundaries, while emphasizing that those rules, boundaries etc. cannot be accepted if they violate children's rights. Similarly, family conflict, loss of parents and divorce are the main reasons for children to be taken under protection, counseling should be offered to children who have family problems by following the family and the child, with the cooperation of the psychological counselor, guidance teacher and social worker. Similarly, the prevention of school dropouts and the follow-up of children are among the activities that can be implemented in this context.

Carrying educational activities on children's rights with families is another suggestion that is derived from the research results. At the point where protective and preventive studies are not enough, important duties fall on the professional staff working in social service institutions and organizations. Therefore, the workload of the social workers should be alleviated by increasing the number of professional staff working in these institutions and 
organizations, and in this direction, the professional staff can provide more effective and efficient services for children. Furthermore, social workers should carry out studies to increase the awareness of other staff working in these institutions and organizations on the subject of neglect and abuse, within the educational role of the social worker.

Likewise, the institutions responsible for child protection are not only schools or social service organizations, but the entire society, especially every person working in the field of child welfare. In this respect, activities to create awareness on the topics such as children's rights, violence against children, child labor, early and forced marriages should be carried out in cooperation with the public, civil society and media, and reporting mechanisms should be taught. Finally, qualitative and quantitative studies that deal with the experiences of children in need of protection before, during and after institutional care as a whole should be conducted.

Keywords: children in need of protection, child neglect and abuse, social work. 


\section{Giriş}

Çocukluk çağı yaşantısı bireyin genel iyilik halinin temel belirleyicisi olmasa da iyilik halinde önemli etkenlerden biri olarak gösterilebilmektedir. Çocukluk çağında travmatik deneyimler yaşayan bireylerin yetişkinlikte ilişki problemleri, depresyon, anksiyete, intihar, madde kullanımı gibi risklerle karşı karşıya olduğu belirtilmektedir (Bethell vd., 2014; Oral vd., 2016). Çocuklukta deneyimlenen kurum bakımının ise zorunlu olarak travmatik bir deneyim olduğu söylenemese de çocuğun biyo-psiko-sosyal gelişiminde hayati önem arz ettiği ve olumsuz yaşam deneyimleri içerdiğinde travmaya dönüşebileceği söylenebilmektedir. Nitekim korunmaya muhtaç ya da ihtiyacı olan çocuk ${ }^{1}$, tanımı itibariyle anne babası olmayan, ihmal ve istismar sebebiyle bedensel, zihinsel, sosyal, ruhsal ve ahlaki gelişimleri ya da güvenlikleri tehlikede olan veya suça sürüklenmiş çocukları işaret ettiğinden olumsuz yaşam deneyimlerini içinde barındırmaktadır (2828 Sosyal Hizmetler ve Çocuk Esirgeme Kurumu Kanunu, 2014; 5395 Sayılı Çocuk Koruma Kanunu, 2005). Tanımda gösterdiği gibi, korunma altına alınan çocuklar olumsuz çocukluk çağı deneyimlerine sahip olan bireyler olmakla birlikte bu olumsuz deneyimlerin travmaya dönme riski oldukça yüksektir.

$\mathrm{Bu}$ riski azaltabilmenin çocuk refahı alanında koruyucu ve önleyici tedbirlerle mümkün olduğu söylenebilmektedir. Çözüme giden doğru yolu bulmanın ise öncelikle sebepleri anlamaktan geçtiği düşünülmektedir. $\mathrm{Bu}$ sebeple çocukların korunmaya ihtiyacı olan çocuk ya da suça sürüklenmiş çocuk olmasının altında yatan nedenleri, kurum bakımının doğurduğu risklerle beraber anlamanın koruyucu önleyici tedbirler için başlıca adımlardan olduğu söylenebilmektedir. Bu doğrultuda bu araştırma geçici süreyle kurum bakımını deneyimlemiş olan 13-18 yaş aralığındaki çocukların korunma altına alınma sebeplerine ve deneyimlerine odaklanmaktadır. Bu sebeplerin ve deneyimlerin öğrenilmesinin, öncelikle çocukluk çağı olumsuz yaşantılarıyla neredeyse her gün karşılaşabilecek sosyal hizmet uzmanlarına yönelik önemli bir teori ve uygulama bilgisi sunacağ d düşünülmektedir. Benzer şekilde, kurum deneyimi öncesindeki olumsuz deneyimin, kurum bakımı sonrasında ortaya çıkan toplumsal yaşama katılım, eğitim, istihdam, yoksulluk, aile yaşamı, sosyal yaşam ve sağlık durumları gibi birçok sorunla düşünüldüğünde, bu sorunların ortaya çıkmadan önlenmesine yönelik önemli bir bilgi kaynağı oluşturacağına inanılmaktadır. Buna paralel olarak, ergenlik döneminin psikolojik, biyolojik, zihinsel ve sosyal gelişim için kritik bir dönem olduğu, ergenliğin kendine has zorluklarının yanında kurum bakımı deneyiminin de bu sorunları derinleştireceği varsayımı göz önünde bulundurulduğunda, korunma ihtiyacını doğuran sebeplere çocukların kendi anlatıları üzerinden odaklanmanın bu alanda birincil çalışanlardan olan sosyal hizmet uzmanlarının uygulamalarına katkı sağlayacağı düşünülmektedir. Son olarak, konuyla ilgili araştırmaların çoğunlukla kurum bakımında kalmanın çocuklar üzerindeki etkisini ve etiketlenme durumlarını (Çayır, 2019), baş etme yöntemlerini (Aşık, 2006), uyum sürecinde karşılaştıkları sorunları ve sosyal destek

\footnotetext{
${ }^{1}$ Literatürde korunma altına alınma gereksinimi duyan çocuklar için korunmaya muhtaç çocuk ya da korunmaya ihtiyacı olan çocuk kavramlarının kullanıldığı görülmektedir. 18 yaşından küçüklerin korunma ihtiyacı bir muhtaçlık veya acizlik durumunu değil, bir hak ihlalini göstermesi sebebiyle çalışma boyunca muhtaçlık yerine ihtiyaç kavramı kullanılacaktır.
} 
kaynaklarını (Boduroğlu, 2016), psikolojik dayanıklılık düzeylerini (Turgut, 2018), bağlanma biçimlerini (Yüksel \& Öncü, 2016) ve kurum bakımının çocuklar üzerindeki olumsuz etkilerini (Erol, 2004) incelediği görülmektedir. Bununla birlikte çalışmaların daha çok kurum bakımı geçmişi olan bireylerin deneyimlerini keşfetmeye odaklandığı, dolayısıyla örneklemlerinin daha çok kurumdan yaşının dolması, evlat edinilme veya koruyucu aile yanına yerleştirilme nedeniyle ayrılan bireylerden oluştuğu görülmektedir. Geçici süreyle kurum deneyimi yaşamış ve biyolojik aileye geri döndürülen çocuklara yönelik ulusal alanyazındaki bilgiler ise sınırlıdır. Bu doğrultuda geçici süreyle kurum deneyimi yaşamış ve ailelerinin yanına dönmüş bu özel müracaatçı grubuna yönelik bilgi birikiminin literatürdeki bu eksikliğe katkı sunacağı düşünülmektedir.

Bu bilgiler doğrultusunda, araştırma literatürdeki bilgi eksikliğine, sosyal hizmet uygulamasına ve sosyal politikalara katkı sunmayı amaçlayarak geçici süreyle kurum deneyimi yaşamış olan 13-18 yaş aralığındaki kız çocuklarının kuruma geliş sebeplerine ve deneyimlerine odaklanmaktadır.

\section{Çocukların Korunma Altına Alınma Sebepleri ve Kurum Bakımının Olumsuz Etkileri}

Kentleşme, göç, artan işsizlik ve yoksulluk gibi etmenlerin ortaya çıkardığg toplumsal değişim, aileleri de değiştirmekte ve dönüştürmekte, bu etmenler aileleri olumsuz yönde etkilediği zaman çocukların korunmaya ihtiyacı olan birey haline gelmelerine de neden olabilmektedir (Yolcuoğlu, 2009). Çocukların korunmaya ihtiyacı olan çocuk olmaları ise zaman, mekân ve bağlama göre değişebilmektedir. Başka bir deyişle, bir ailede yoksulluk çocukların korunma ihtiyacını ortaya çıkarırken, başka bir aile de bu sebep ev içi şiddet olabilmekte, başka bir ailede ise ihmal ve istismar korunma sebebi olabilmektedir. Dolayısıyla sebepler her vaka özelinde değişebilse de genel olarak ev içi şiddet; fiziksel, duygusal, cinsel, ihmal ve istismar, refakatsiz çocuk olmak, suç çetelerine üyelik gibi sebepler çocukların korunmaya ihtiyacı olan çocuk statüsünde sayılmalarının başlıca sebepleri olarak gösterilmektedir (UK Department of Education, 2018). Türkiye özelinde ise aile içi şiddet, ailenin parçalanması, boşanma, şiddetli geçimsizlik ve yoksulluk çocukların korunma altına alınmasında başlıca sebepler olarak gösterilmektedir (Uluğtekin, 1993; Yüceer, 2012). Bu doğrultuda kurum bakımı ihtiyacı; ebeveyn yokluğu ve ekonomik yetersizlikler (Çayır, 2019), ebeveynlerin boşanması, (Varol, 2017) çocuğun fiziksel, duygusal veya cinsel olarak ihmal veya istismar edilmesi (Gülümser, 2005; Sadak, 2019) ve aile içi şiddet (Lök, Başoğul \& Öncel, 2016) ile açıklanmaktadır. $\mathrm{Bu}$ nedenlerden özellikle aile içi fiziksel şiddet, etkileri daha kolay saptanabilen bir şiddet türü olması sebebiyle çocuğun aile yanından alınıp korunma altına alınmasına neden olabilmektedir. Bununla birlikte, aile sisteminin zarar görmesiyle beraber çocuk işçiliği, suça sürüklenme, madde bağımlılığı ve çocuk evliliklerinin tespit edilmesi çocukların korunmaya ihtiyacını doğurmaktadır (Barış \& Taylan, 2020).

Türkiye'de çocukların korunması ile ilgili ön plana çıkan kurum Aile ve Sosyal Hizmetler Bakanlığı'na bağlı Çocuk Hizmetleri Genel Müdürlüğü'dür. Korunmaya ihtiyacı olan veya suça sürüklenen çocuklara korunma ve bakım sağlayan Çocuk Hizmetleri Genel Müdürlüğü; hizmetlerini çocuğun bakımının aile yanında desteklenmesi, evlat edindirme, koruyucu aile ve kurum bakımı modelleriyle 
sunmaktadır. Bu modellerden aile yanında destekleme; sosyal ve ekonomik nedenlerle çocuğun bakımını sağlayamayan ailelere destek olarak çocuğun aile yanında büyümesinin sağlanması, evlat edindirme; çocuğu evlat vermek suretiyle çocuğun yeni bir aile yanında biyo-psiko-sosyal gelişiminin sağlanması, koruyucu aile ise biyolojik aile yeniden çocuğun bakımını sağlayacak duruma gelene kadar ya da çocuk kendi ayakları üstünde durabilen bir birey olana kadar sağlanan bakım olarak özetlenebilmektedir. Kurum bakımı; devlete bağlı kuruluşlar içerisinde korunmaya ihtiyacı olan çocukları dış tehlikelerden koruyan, bakınma ve korunma gereksinimini sağlayan, beslenme, barınma, eğitim, sağlık ihtiyaçlarını karşılayan bir sistem olarak tasarlanmıştır (Turgut, 2018). Türkiye'de kurum bakımı modelleri; çocuk yuvaları, yetiştirme yurtları, çocuk ve sevgi evleri ile çocuk destek merkezleridir (Tuncer \& Erdoğan, 2018). Yetiştirme yurtları yüksek kapasiteli koğuş tipi yapılar olup, çocukların korunması, bakımı, eğitimi ve çalışma hayatına katılımı gibi gereksinimlerini sağlamakla görevli yatılı sosyal hizmet kuruluşlarıdır (2828 Sosyal Hizmetler Kanunu, md.3). Türkiye'de özellikle son 10 yıldır kalabalık olan koğuş tipi yuva, yurtlar ve yetiştirme yurdu olarak adlandırılan yapılanmalar yerine çocuk evleri sitesi, çocuk evi ve çocuk destek merkezleri yaygınlaştırılmaya çalışılmaktadır (Güven \& Bilir, 2020, s. 100). Çocuk evleri; "apartman dairesi veya müstakil dairelerde, genelde 5-6 çocuğun bir aile ortamına en yakın şekilde bakımlarının sağlandığı ev tipi kuruluşlar" olarak (Güven \& Bilir, 2020, s. 101), çocuk evleri sitesi ise çocuk evlerinin bir arada bulunduğu yerleşkeler olarak tanımlanmaktadır. Çocuk Destek Merkezleri ise suça sürüklenme, suç mağduru olma, sokakta yaşama gibi çeşitli sebeplerle korunmaya ihtiyacı olan çocukların ihtiyaçları göz önünde bulundurularak farklı hizmet modelleri sağlayan kuruluşlardır (Çocuk Hizmetleri Genel Müdürlüğü, 2021). Görüldüğü üzere, Türkiye'de çocuk koruma alanında korunmaya ihtiyacı olan çocukların bakımı ve korunmasının sağlandığı yurtları ev ve aile bakımına yakınlaştırmak amacıyla, daha küçük ve az sayıda çocuğun kaldığı sevgi ve çocuk evlerine dönüştürme ve bu evleri yaygınlaştırma politikası yürütülmektedir. Çocuk koruma sisteminde yürütülen bu politika değişimi Şekil 1' de niceliksel olarak görülebilmektedir.

\section{Şekil 1.}

\section{Çocuk koruma Sisteminde Kuruluş Dönüşümü}

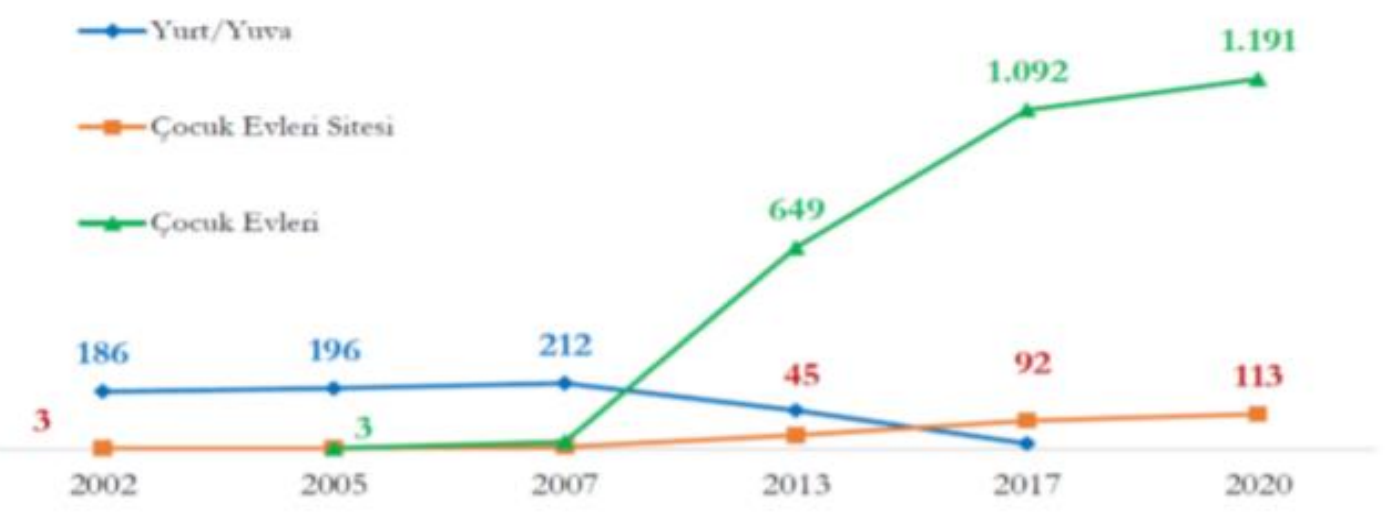

Kaynak: Çocuk Koruma Sisteminde Kuruluş Dönüşümü (Güven ve Bilir, 2020, s. 99). 
Şekil 1'de de görüldügü gibi çocukların aile sıcaklığına daha benzer yerlerde büyümesini amaçlayan bu düzenlemeler ve çocuk evlerinin artan sayısı her ne kadar olumlu gelişmeler olsa da, kurum deneyimi öncesi olumsuz yaşantıların ve kurum deneyiminin ortaya çıkardığı bazı olumsuz etkileri gidermeye yetmemektedir. Nitekim araştırmalar kurum deneyimi olan çocukların saldırganlık, depresyon, anksiyete, hiperaktivite gibi davranışları sergileme düzeylerinin diğer çocuklara göre daha yüksek olduğunu ortaya koymaktadır (Cebe, 2005; Erkan, 1995; Erol, Öztop \& Özcan, 2018; Kutlu, 1998; Sarıaltın, 2017; Yüksel, 2016). Benzer şekilde kurum deneyimi sonrasında bireylerin yetişkinlik dönemlerinde; barınma, ekonomi, çalışma hayatı, sağlık hizmetlerine erişim, sosyal yaşama uyum ve psikolojik problemler, etiketlenme ve dışlanma sorunları yaşadıklarını göstermektedir (Boduroğlu, 2016; Çayır, 2019; Dutta, 2017; Melkman \& Benbenishty, 2018; Sadak \& Y1ldırım, 2020; Turgut, 2018; Yüksel \& Öncü, 2016).

İşsizlik, para yönetimi ve ekonomik yoksunluk kurum deneyimi sonrasında ortaya çıkan başka bir sorun olmaktadır. Kurum bakımından ayrılan bireyler iş bulmakta zorlanmakta, bir işe yerleşinceye kadar ekonomik problemlerle karşı karşıya kalmakta ve bazen bir işe yerleşince bile para yönetimi konusunda sorunlar yaşayarak ekonomik yoksunlukla karşı karşıya kalabilmektedir (Varol, 2017; Turgut, 2018). Bu yoksunluğu aşmak için çekilen kredileri geri ödeyememek, kira borçları ve satın alım gibi alanlarda yaşanan zorluklar nedeniyle bireylerin ekonomik yoksunlukları derinleşebilmektedir (Baker, 2017). Yoksulluk, yoksunluk ve psikolojik problemler başka sorunları doğurabilmekte ve bazı bireyleri uyuşturucu kullanımı ya da suç davranışına yöneltebilmektedir (Gallwey, 2013; Turgut \& Özkan, 2019).

Kurum bakımı sonrası yaşanan ekonomik zorluklar ve işsizlik aynı zamanda kişilerin kurumdan ayrıldıktan sonra dışarıda birlikte yaşayabileceği ailesinin veya bir akrabasının bulunmaması halinde, barınma sorunu yaşamalarına sebep olmaktadır (Turgut, 2018). Bu süreçte bir akrabasının yanında kalanlar ise akrabalarının ya da yakınlarının dışlayıcı ve ayrımcı tutumları sebebiyle barınma sorunu yaşayabilmekte ve evsiz kalabilmektedir (Sadak \& Yıldırım, 2020). Nitekim Boduroğlu (2016) kurum bakımından ayrıldıktan sonra kısa süre akrabalarının yanında kalan bireylerin, akrabalarıyla yaşadıkları sorunlar sebebiyle hastanelerde, parklarda, iş yerlerinde ve camilerde kaldıklarını belirtmektedir. Görüldüğü üzere kurum bakımı sonrası yaşanan problemler iç içe geçmekte, birbirlerinin nedeni ve sonucu olmaktadır. Ekonomik yoksunluk barınma sorununa, barınma sorunu psikolojik sorunlara, psikolojik sorunlar sosyal sorunlara dönüşerek bireylerin çözümü zor bir döngüye girmesine sebep olmaktadır.

Sonuç olarak, aile içi geçimsizlik, boşanma, ebeveyn kaybı ve yoksulluğun çocuğun korunma altına alınmasında başlıca sebepler olduğu, kurum öncesi olumsuz yaşam deneyimleri ve kurum deneyiminin çocuklarda psikolojik ve sosyal sorunlar ortaya çıkardığı, kurum deneyimi sonrasında ise bu sorunların derinleşerek barınma, istihdam, sosyal yaşam sorunlarına yol açabileceği görülmektedir. Ancak bu sonuçların kurum deneyimini uzun süre yaşamış çocuklarla yapılan araştırmalarda ortaya çıktığını, geçici süre kurum deneyimi yaşayan bireylerin kuruma geliş sebeplerini ve deneyimlerini inceleyen bir araştırmaya ulusal alanyazında rastlanmamıştır. Bu doğrultuda araştırma bu deneyime sahip bireylerin deneyimlerini öğrenmek, bu özel müracaatçı grubuyla çalışan ve çalışacak sosyal hizmet uzmanlarına 
yönelik teori ve alan bilgisi sağlamak ve bu alanda oluşturulacak sosyal politikalara katkı sunmak amaçlarılyla gerçekleştirilmiştir.

\section{Yöntem}

$\mathrm{Bu}$ araştırma geçici süre kurum deneyimi yaşamış 13- 18 yaş aralığında kız çocuklarının korunma altına alınma sebeplerini ve deneyimlerini kendi anlatıları üzerinden öğrenmeyi amaçlamıştır. Araştırma kişilerin yaşanmış deneyimlerini (lived experience) bizzat kendilerinden öğrenmeyi ve kurum deneyiminin ihtiva ettiklerini açımlamayı amaçlaması sebebiyle nitel araştırma deseninde ve fenomenolojik yaklaşımla tasarlanmıştır.

\section{Veri Oluşturma Süreci}

Araştırma, yazarlardan birinin gönüllü eğitim ve danışmanlık verdiği, Konya'nın sosyo-ekonomik koşulları düşük bir bölgesinde bulunan dernekten annesiyle beraber hizmet almaya gelen ve kurum deneyimi bir çocukla karşılaşmasıyla başlamıştır. Kartopu örnekleme yöntemiyle araştırmanın diğer katılımcılarına ulaşılarak toplamda 10 çocuğa ulaşılmıştır. Veri oluşturma süreci, araştırmacılar tarafından literatür temel alınarak oluşturulan ve çocukların korunma altına alınma sebepleri, kurum deneyimi ve aileye dönüş süreçlerini öğrenmek üzere hazırlanmış yarı yapılandırılmış derinlemesine görüşme formu aracılığıyla ve yapılandırılmamış gözlem tekniğiyle Ağustos-Ekim 2020 ayları arasında oluşturulmuştur. Bu çalışma için, Selçuk Üniversitesi Etik kurulundan 06.07.2020 tarihli ve2020/638 sayılı karar ile izin alınmıştır (Ek-1).

\section{Çalışma Grubu}

Araştırmanın çalışma grubunu çeşitli sebeplerle geçici olarak kurum deneyimi yaşamış yaşları 1318 arasında değişen $10 \mathrm{kız} \mathrm{çocuğu} \mathrm{oluşturmaktadır}{ }^{2}$. Çocukların sosyo-demografik bilgilerinin yanı sıra kuruma geliş nedenleri ve kurumda kalma süreleri Tablo 1'de sunulmaktadır.

\footnotetext{
${ }^{2}$ Araştırmaya tek katılım kriteri kurum bakımı deneyimidir, ancak ulaşılan katılımcılar bu yaş grubundaki kız çocukları olmuştur.
} 
Tablo 1.

Katılımcıların Sosyo-demografik Bilgileri, Kuruma Geliş Sebepleri ve Kurumda Kalma Süreleri

\begin{tabular}{|c|c|c|c|c|c|}
\hline & $\begin{array}{l}\text { Çocuğun } \\
\text { Yaş1 }\end{array}$ & $\begin{array}{r}\text { Kuruma } \\
\text { Gidiş Yaş1 } \\
\end{array}$ & $\begin{array}{l}\text { Eğitim } \\
\text { Durumu }\end{array}$ & $\begin{array}{l}\text { Kuruma Gidiş } \\
\text { Nedeni }\end{array}$ & $\begin{array}{r}\text { Kurumda } \\
\text { Kalınan Süre } \\
\end{array}$ \\
\hline Katılımeı 1 & 13 & 11 & Ortaokul 7. sinif & $\begin{array}{l}\text { Ablayla tartışmadan } \\
\text { dolayı evden kaçma }\end{array}$ & 2 ay \\
\hline Katılıme1 2 & 16 & 13 & Lise 10. sinif & $\begin{array}{l}\text { Anneyle tartışmadan } \\
\text { dolayı evden kaçma }\end{array}$ & 3 ay \\
\hline Katılımc1 3 & 14 & 13 & $\begin{array}{c}\text { Ortaokul } 8 . \\
\text { Sinıf terk }\end{array}$ & $\begin{array}{l}\text { Babayla tartışmadan } \\
\text { dolayı evden kaçma }\end{array}$ & 3 hafta \\
\hline Katılımc1 4 & 14 & 11 & Ortaokul 8. sinif & $\begin{array}{l}\text { Anneyle tartışmadan } \\
\text { dolayı evden kaçma }\end{array}$ & 2 ay \\
\hline Katılıme1 5 & 17 & 16 & Lise 11. sinif & $\begin{array}{l}\text { Babayla tartışmadan } \\
\text { dolayı evden kaçma }\end{array}$ & 1 ay \\
\hline Katılımc1 6 & 14 & 13 & Ortaokul 8. sinif & $\begin{array}{l}\text { Babayla tartışmadan } \\
\text { dolay1 evden kaçma }\end{array}$ & 4 ay \\
\hline Katılıme1 7 & 16 & 15 & Lise 10. Sinıf & $\begin{array}{l}\text { Baba şiddetinden dolay } 1 \\
\text { evden kaçma }\end{array}$ & 5 ay \\
\hline Katılımc 8 & 18 & 17 & Lise 12. Sinıf & $\begin{array}{l}\text { Babayla tartışmadan } \\
\text { dolay1 evden kaçma }\end{array}$ & 2 ay \\
\hline Katılıme1 9 & 15 & 16 & Lise 9. Sinıf & $\begin{array}{l}\text { İlgisizlik düsüncesinden } \\
\text { dolayı evden kaçma }\end{array}$ & 1 ay \\
\hline $\begin{array}{l}\text { Katılımc1 } \\
10\end{array}$ & 15 & 13 & Lise 9. Sinıf & $\begin{array}{l}\text { Ebeveynle tartışmadan } \\
\text { dolay1 evden kaçma }\end{array}$ & 1 ay \\
\hline
\end{tabular}

\section{Veri Analizi}

Görüşmeler katılımcıların istekleri doğrultusunda not alınarak kaydedilmiş, gerçekleştirilen görüşmeler MAXQDA programına aktarılarak tematik analiz yöntemiyle analiz edilmiştir. Nitel araştırmalarda tematik analiz yönteminde izlenen yol; tümevarım ya da tümden gelim yöntemi olabilmekte ve araştırma amacına göre her iki yöntem beraber kullanılabilmektedir. Tümden gelim yönteminde; araştırmacı literatürden elde ettiği temaları veri setine uygulayarak temalarını oluştururken, tüme varım yönteminde; kodlama, kategorileştirme ve temalaştırma süreci izlenmektedir. Araştırmada tüme varım ve tümden gelim teknikleri beraber kullanılmıştır. Fiziksel şiddet ve cinsel şiddet araştırmanın tümden gelim yönteminin kullanıldığı temalara örnek verilebilmektedir. Tümevarım yönteminde kullanılan kod, kategori ve temalaştırmaya örnek olarak ise, "evden kaçma”nın bir kod, "evden kaçma sebepleri”nin bir kategori ve bir cezalandırma stratejisi olarak evden kaçış"ın bir tema oluşu örnek verilebilmektedir. Analiz sonucunda "bir cezalandırma stratejisi olarak evden kaçı̧̧", "fiziksel şiddet”, "cinsel şiddet ve aile desteğinin önemi”" ve "kurum deneyimi sonrası aileye geri dönüş" çocukların korunma ihtiyacı bulunan çocuk olma sebeplerini ve kurum deneyimlerini açımlayan dört temel tema olarak keşfedilmiştir.

\section{Bulgular}

Çocuklarla yapılan derinlemesine görüşme ve gözlem sonuçlarında çocukların tamamının evden kaçmak sebebiyle kurum bakımına alındığı anlaşıımıştır. Çocukların hepsi evden kaçsa da evden kaçma sebeplerinin ailelerini cezalandırmak, fiziksel şiddet ve cinsel şiddet gibi farklı sebeplerden kaynaklandığ 1 görülmektedir. Çocukların aileye dönüş sürecinde kurum bakımını ise genel olarak pişmanlıkla nitelendirdikleri bulunmuştur. Bu doğrultuda araştırmanın temalarını; "bir cezalandırma stratejisi olarak 
evden kaçış", "fiziksel şiddet”, “cinsel şiddet” ve "kurum deneyimi sonrası aileye geri dönüş" oluşturmaktadır.

\section{Bir Cezalandırma Stratejisi Olarak Evden Kaçış}

Aile içi iletişimin sağlıklı bir şekilde gerçekleşememesi, çocuklara verilen yanlış bazen de aşırı cezalar ve fiziksel şiddet çocukların evden kaçmasına sebep olabildiği gibi, çocukların anne baba otoritesini reddetme eğilimleri de evden kaçarak korunma altına alınmalarına sebep olabilmektedir. Bu temada çocukların evden kaçma sebepleri; isteklerinin yerine getirilmemesi ve yakın partner ilişkilerinin ailesi tarafından onaylanmaması olarak açığa çıkmıştır. Çocukların bu gibi konularda aileleriyle sorun yaşamaları durumunda evden kaçışı ailelerini cezalandırma stratejisi olarak kullandıkları görülmüştür.

Çocukların anlatıları; ailelerin isteklerini yerine getirmedikleri durumlarda evden kaçışı bir çözüm olarak gördüklerini göstermektedir. Bu istek bazen cep telefonu gibi maddi bir istek olabileceği gibi, istediği kişiyle sevgili olabilmek gibi manevi bir istek de olabilmektedir. Babası telefon almadığ 1 için evden kaçtığını ifade eden Katılımcı 1 o dönemdeki duygularını: "Ne var yani telefon kullanmak istediysem? Telefonum kırıld, yenisini istediğimde yok dediler, almayacă̆ız falan..." şeklinde ifade etmiştir. Çocukların özellikle erkek arkadaşlarından dolayı çıkan sorunlarda evden kaçışı bir çözüm olarak gördükleri gözlemlenmiştir:

Benim bir sevgilim vardı. Bunu ilk öğrenen annem oldu. Kızdı işte... Babama söylediğinde babam telefonumu elimden aldı ve dışarı çıkmama izin vermedi. Ben önce çok kızdım ve bir şekilde evden kaçtım. Polisler beni bulduğunda eve gitmek istemediğim için çocuk evine götürdüler (Katılımcı 3).

Ailem benim iyiliğimi düşünüyormuş, kötü alışkanlığı ve sabıkası olan biriyle görüşmemi hatta nişanlanmamı istememeleri doğal ama bana neden görüşmeme izin vermediklerini söylemedikleri için ben yanlış anladım bu yüzden annemle kavga ettim, keşke böyle olmasaydı (Katılımcı 4).

Annem erkek arkadaşım olduğunu öğrendiğinden beri beni sürekli uyarıyor, görüşmemi istemiyordu (Katılime1 7).

Katılımcıların anlatılarından, ebeveynlerin çocuklarının yakın partner ilişkisine sıcak bakmadıklarını ve tepkilerini çocukla konuşarak ikna etmek yerine evden dışarı çıkmaya izin vermemek ya da cep telefonuna el koymak gibi yollarla gösterdikleri anlaşılmaktadır. Ailelerin bu tepkiyi çocuklarının yaşları sebebiyle vermiş olabilecekleri gibi sosyo-kültürel düşünceleri ve inançlarıyla ilintili olarak da vermiş olabilecekleri düşünülmektedir. Ancak, ailelerin motivasyonu her ne olursa olsun, çocuklarla sağl1klı iletişim kurulmamasının ve çocuğun anlamlandıramadığı ceza yöntemlerinin kullanılmasının, çocukların aileyi cezalandırmak ve yakın partnerleriyle görüşmek adına evden kaçmalarına sebep olduğu görülmüştür. Bununla birlikte ebeveynlerin çocuklarla yakın partner ilişkisi ve sınırlar hakkında konuşmaması ve çocukların bu ilişkileri ailenin bilgisi dışında yaşamalarının, hem çocukların riskli davranışlar sergilemesine hem de ebeveyn çocuk iletişimde sorunlara yol açtığı görülmüştür:

Whatsapp'tan sevgilime attığım açık fotoğraflarımı babam gördü ve telefonumu elimden aldı, babama neden telefonumu aldın dedim o da "seni bu halinle ifşa etmesinler diye telefonunu aldım" dedi. Ben de çok ağladım, yani babamın o söylediği beni çok kırdı (Katılımcı 6). 
Katılımcıların anlatısı özellikle yakın ilişkilerin ilk defa deneyimlendiği ergenlik döneminde çocuklarla sağlıklı ikili ilişkiler hakkında bilgilendirici ve hoş görülü konuşmaların gerçekleştirilmesi gerektiğine işaret etmektedir. Katılımcıların bazıları boşanma, ölüm, ev içi şiddet gibi stres faktörlerinin sağlıklı bir şekilde yürütülemediği ailelerde, çocukların algıladıkları ilgi düzeyindeki düşüklük sebebiyle evden kaçışı bir tepki, ilgi görmek için bir araç olarak kullandıkları da göstermektedir:

Annem ve babam ayrıldılar. Ben annemle kalıyorum işte arada babama gidiyordum. Çok ilgilenmediklerini hissediyordum yani eskisi gibi... Ben de evden kaçtım. Beni polisler bulup çocuk evine götürdü, şimdi pişmanım tabiî ki annem ve babamdan özür diledim, pişmanım dedim, bir daha böyle bir şeyi asla yapmam tabiî ki, onlar beni çok seviyormuş meğer (Katılımc1 9).

Katılımcının ifadelerinde de görüldüğü üzere, boşanma süreci ve sonrasındaki uyum sürecinin çocuk açısından sağlıklı yürüyemediği durumlarda çocuklar anne ve baba sevgisini sorgulayabilmekte, kendilerini ilgilenilmeyen ve sevilmeyen bireyler olarak tanımlayabilmekte ve bazen bu durum sebebiyle kendilerini suçlayabilmektedir. $\mathrm{Bu}$ tarz durumlar ortaya çıktığında ise çocuklar evden kaçmayı, sevildiklerini anlamanın ve ebeveynleri cezalandırmanın bir yolu olarak kullanabilmektedir.

\section{Fiziksel Şiddet}

Her ne sebeple olursa olsun kabul edilemeyecek olan fiziksel şiddet; ebeveynler tarafından bir şiddet türü olarak algılanmayıp bazen sadece anne ve babalarından öyle gördükleri için bazen de çocukları eğitmenin bir yolu olarak meşrulaştırılmaktadır. Katılımcıların anlatıları, ebeveynlerinin otoritelerini sağlamlaştırmak, isteklerini yaptırmak ya da başka güdülerle uyguladıkları fiziksel şiddet sebebiyle evden kaçtıklarını göstermektedir. Bununla birlikte ebeveynlerin aile içi iletişimle rahatlıkla çözülebilecek sorunları şiddetle çözmeye çalışmalarının sorunları derinleştirerek çocukların korunma altına alınmasıyla sonuçlandığı görülmektedir. Bir katılımcı deneyimini “Annem beni dövdü. Yani annem elime eliyle vurdu. Daha hayatında bana bir kere bile vurmuş değildi. Ben de annem beni dövdüğü için evden kaçtım” (Katılımc1 2) şeklinde ifade etmiştir. Benzer bir şekilde, başka bir katılımcının anlatısında, arkadaş ve eğitim ilişkilerinin sağlıklı ebeveyn ilişkisiyle çözüm bulabileceği bir sorunun şiddetle sonuçlandığı ve çocuğun evden kaçtığını görülmektedir:

Babam aslında beni çok sever, beni dövdüğünü hatırlamam belki ben abartıyorum ama bana tokat attığında çok zoruma gitti. Nasıl söyleyeyim yani tamam benim de okulda çok devamsızlı̆ım vardı, ben de okuldan kaçıyordum, arkadaşlarımla falan görüşüyordum. İşte babam öğrendiğinde okula geldi, orda bana attığı tokat beni çok üzdü. Ertesi gün ise okuldan kaçtıktan sonra eve gitmedim sonra arkadaşımdan çocuk evini biliyordum, oraya gittim (Katılımc15).

Katılımcıların sadece ebeveyn ilişkilerinde değil, diğer aile üyeleriyle yaşadıkları ve şiddetle sonuçlanan sorunlarında çocukların evden kaçmasına sebep olduğunu göstermektedir:

Tabiî ki abim beni sürekli döven biri değil, yani biz onunla çok şakalaşırız bir iki defa vurmuşluğu vardır en fazla (Katılımc1 2).

Annem ve babam boşandıktan sonra ben anneannem ve dedemin yanında kaldım. Onlar bana bakıyordu. Ya bugüne kadar ne annem ne de babam bana vurdu. Neymiş? Ben eve gelmiyormuşum. Dedemle tartıştım, o da bana terliğini firlattı. Şimdi düşününce annem ve babam yokken anneannemle dedem bana anne ve baba yokluğu hissettirmediler, bana bir defalık kızmalarına kızmamalıydım (Katılımcı 10). 
Ablamla sürekli tartışırdık ama ben daha küçük olduğum için her zaman suçlu o olurdu. Annem ve babam da sürekli tartışmalarımızdan sonra onu uyarırdı. Onu çok üzdüğümü biliyorum ama onunla tartıştığım için evden kaçtım. Keşke kaçmasaydım (Katılımcı 1).

Görüldüğü üzere ailedeki diğer sistemlerle kurulamayan işlevsel iletişim çocukların evden kaçarak tepki göstermelerine yol açmaktadır. Katılımcılardan sadece biri başka bir çare bulamadığ için evden kaçtığını anlatmıştır:

Babam ben arkadaşlarımla dışarı çıktığım için döverdi, öfke kontrol problemi var en ufak bir şeyde hemen şiddete yönelir. Yani ben ne yaparsam onun için suç oluyordu. Annem de karşı koyamıyordu, ben de evden kaçtım, yapacak bir şeyim yoktu, ne yapabilirdim? (Katılımcı 7).

Katılımcıların anlatılarından da görüldügü üzere, aile içi iletişimin sağlıklı yürütülememesi çocukların evden kaçarak kurum deneyimi yaşamalarına yol açmıştır. Anlatılar sadece ebeveyn çocuk sisteminin değil, eşler arası, kardeşler arası ve ebeveyn çocuk arasındaki ilişkilerin bir bütün olarak sağlıklı işlediği zaman roller, sınırlar ve cezaların ölçülü ve iyi belirlenemediği aile yaşantılarının çocukların korunma altına alınmasıyla sonuçlandığını göstermektedir.

\section{Cinsel Şiddet ve Aile Desteğinin Önemi}

Katılımcıların hepsi evden kaçmaları sonucunda korunma altına alındıklarını ifade etse de, gerçekleştirilen derinlemesine görüşmelerde cinsel şiddet öyküsü ortaya çıkmış, çocukların baş edemedikleri cinsel şiddet deneyiminin aile içi iletişim sorunlarıyla birleşerek evden kaçışla sonlandığ görülmüştür. Katılımcıların anlatıları, cinsel şiddetin erkek arkadaşlarından, tanıdıklarından, akrabalarında ya da aile içinden geldiğini göstermektedir:

11 yaşındaydım. Ben onun bana zarar vermeyeceğini düşünüyordum. Annesi ile tanıştıracağını söylediği için evine gittim. Annesi evde yoktu, yani evde hiç kimse yoktu... benim tecavüz olayım olmuştu işte (Katılımcı $6)$.

Abimin yanına gittim. Annem gitme dedi ama ben gittim. Orada abimin çok yakın bir arkadaşı vardı. Bilemezdim ki o bana tecavüz etti. Sonra hiç kimseye söylemedim. Psikolojim bozuldu. Bir yıl sonra anneme anlattım (Katılımc1 1).

Katılımcının bir yıl boyunca bu travmatik deneyimi içinde taşıması çocuğun cinsel şiddet ve çaresizlikten dolayı korktuğunu göstermektedir. Oldukça sık karşılaşılan bu tarz durumlar aile içinde yaşandığında ise çocuğun korku, kaygı ve çaresizlik düzeyi kendisine inanılmayacağı bazen de bizzat inanılmaması sebebiyle artmaktadır. Nitekim eniştesinin süregelen cinsel istismarı sebebiyle kurum deneyimi yaşayan başka bir katılımcı deneyimlerini aşağıdaki gibi ifade etmiştir:

Annem ve babam çalıştığı için evde yalnız kalıyordum. Yani insan yalnız kalınca sıkııır ben de evli olan ablamın yanına gidiyordum. Eniştem beni taciz ediyordu. Ablama söyledim, o inanmadı bana. Sonra kendi gözüyle gördü (Katılımcı 3).

Katılımcıların anlatılarında da görüldüğü gibi cinsel şiddet hem açıklanması zor hem de yakınlardan geldiğinde diğer yakınların inanmadığı bir şiddet türü olarak açığa çıkmaktadır. Katılımcıların hepsinin evden kaçtı̆̆ için korunma altına alındıklarını anlatmaları, ancak bu anlatının peşi sıra gelen cinsel şiddet öyküsü çocukların cinsel şiddetle yönelik tepkilerini evden kaçarak verdiklerini göstermektedir. Bununla birlikte, cinsel şiddet sonrası ailenin sağlıklı desteğinin ise çocukların bu deneyimle sağlıklı baş etme 
mekanizmaları geliştirebildiklerine katkı sunduğu söylenebilmektedir. Nitekim katılımcılar korunma altına alındıktan ve ailelerine geri döndükten sonra ailelerinden aldıkları desteğin profesyonel destekle beraber cinsel şiddet deneyimine yönelik baş etme mekanizması geliştirilmesinde etkili olduğunu belirtmiştir:

Anneme söylediğimde şok oldu. Söylemezdim ama ben de dayanamıyordum artık. O da şüpheleniyordu, ben de bir şey olduğunu sonra anlattım. Annem hep benim yanımda oldu. Dava açtık o kişiye, psikoloğa gittim birkaç ay (Katılımcı 1).

Psikoloğa gidince toparladım, psikoloğa gittim o şekilde atlattım, annem ve babam hep yanımdaydı psikolojik destek aldım (Katılımc1 8).

Cinsel şiddet; yaş, toplumsal cinsiyet, eğitim, statü fark etmeksizin tüm gruplar için baş edilmesi zor bir deneyimdir. 13-18 yaş grubunun gelişim çağında özel bir dönem olduğu göz önünde bulundurulduğunda, cinsel şiddetle baş etme de aile içi mekanizmaların kullanılması yeterli olmayabilmekte, sağlıklı aile içi iletişim, sosyal destek ve profesyonel desteğin bir arada sunulması gerekebilmektedir. Katılımcıların ifadelerin de görüldüğü üzere bu destek mekanizmalarından özellikle aile desteğinin sağlıklı bir şekilde sunulmaması çocukların tepkilerini evden kaçmak gibi yollarla göstermelerine sebep olmaktadır.

\section{Kurum Deneyimi Sonrası Aileye Geri Dönüş}

Katılımcıların çoğunluğunun kurum deneyimlerinden memnun olmadıkları, özellikle evden kaçmayı bir cezalandırma stratejisi olarak kullanan katılımcıların pişmanlıklarını dile getirdikleri, aile içindeki kural, rol ve sınırlılıkları kabullenmeye başladıkları görülmüştür:

Hatalı olduğumun farkındayım ama sonradan pişman oluyor insan. İlk başta çok kızmıştım ona şimdi anladım onlar sadece beni düşünüyormuş (Katılımc1 1).

Keşke hiç böyle bir şey yaşamasaydım, çok pişmanım (Katılımcı 3).

Annem ve babam boşandı, demiştim zaten. Ben dedem ve anneannemin yanında kalıyordum, yani bana onlar bakıyordu. Bir gün dedemle tartışıtk, konu neydi onu hatırlamıyorum. Ben orada kalınca dedemin ve anneannemin değerini anladım. "Onlara haksızlık etmişim" dedim... Geldiğinde koştum ve ona sarıldım. Onun da gözleri dolmuştu. Onu oraya kadar yormuştum. Dedeme bir daha onları bir daha asla bu şekilde üzmeyeceğim, yanlarından ayrılmayacağım dedim (Katılımcı 10).

Katılımcıların anlatıları ailedeki kural, rol ve sınırların sevginin bir ölçütü olmadığını kurum deneyimi sonrasında anladıklarını da göstermektedir:

Oradayken bir babamla görüştüm ve beni almak istediğini söyledi. Babamın yüzüne baktığımda gördüm ki ağlamaktan gözleri şişmiş ve kızarmış ve benim için dedi ki 'et tırnaktan ayrılır mı?, ben kızımı nasıl burada bırakırım?' dedi (Katılımc1 6).

Hani demiştim ya 'ben 8. sınıftan sonra okumadım' diye, annem de zaten yazları hep çalışır, ben de okuldan sonra çalışmak istediğimi söyledim. Annem de çalışmamı istemedi, babam da... Oku dediler, okuluna git... Ben de onlara çok kızmıştım (Katılımcı 3).

Ben okuldan kaçmıştım, polisler beni kuruma götürdü. Babam devamsızlığımı çok fazla yüzüme vuruyordu, çok katı olduğunu düşünüyordum. Kurumdan ayrılacağım zaman bana kurumda çalışan personel "yarın seni ailene teslim edeceğiz eşyalarını hazırla" demişti. Babam gelecek diye çok heyecanlıydım. Sonra babamın geldiğini gördüm. Çok sevindim, arkadaşlarıma "babam geldi" diye çok sevinerek haber verdim. Sonra sosyal serviste babamla karşılaş̧ım. Koşarak ona sarıldım ve bir an önce eve gitmek istediğimi söyledim (Katılımcı $5)$. 
Katılımcıların anlatılarında da görüldüğü üzere, eğitimle ilgili kurallar, ergenlik döneminin getirdiği hayata ve ailelerine dair sorgulama ailelerin yanlış iletişim kalıplarıyla birleşerek kurum deneyimiyle sonuçlanmış ve çocukların olumsuz yaşam deneyimleri yaşamasına sebep olmuştur. Katılımcıların anlatıları aynı zamanda kurum deneyiminin öğretici olduğunu ve kurum bakımı her ne kadar kaliteli olsa da aile bakımının yerini tutamayacağını göstermektedir:

Ne işim var benim burada?' dedim kendi kendime. Oradayken anladım ki ailemin sevgisini hiçbir yerde bulamam. Onlar beni çok seviyormuş (Katılımcı 4).

Ben kendi kendime diyordum ki ‘ben neden buradayım?'. Yani kendimi düşündüğüm için değil, orada olmam için ciddi bir neden yoktu, gerçekten ihtiyacı olan çocukların da hakkını yemiş olabilirim, yemek yerken bile diyordum ki 'benim bir ailem var bakıma muhtaç değilim, ya başkalarının hakkını yiyorsam?' diye düşünüyordum (Katılımc1 2).

Ben ailem benimle ilgilenmiyor diye evden kaçmıştım. Polisler beni oraya götürmüştü 'eve gitmek istemiyorum' deyince. Sonra 3 gün orada kaldım. O üç gün bana bir ömür gibi geldi. Orası evim gibi değildi. Sonra orada çalışan biri vardı "ben eve gitmek istiyorum" dedim. Geçici koruma olduğu için hemen işlemleri yapmışlar. Annem gelmişti oraya. Annemi ilk gördüğümde dayanamadım ağladım ve anneme sarıldım. Ondan özür diledim ve "bir daha onları terk etmeyeceğim" demiştim anneme (Katılımc1 9).

Katılımcının da dikkat çektiği üzere, istekleri yerine getirilmediği ya da ebeveynlerinin onu sevmediğini düşünen çocukların bu tepkilerini evden kaçarak göstermesi ve bu doğrultuda korunma altına alınması hem çocuklarda olumsuz yaşam deneyimlerine sebep olmakta, hem de kurum kapasitelerinin etkili ve verimli kullanılmasına engel oluşturabilmektedir. Özelikle kalabalık ve toplu olarak kalınan kurumlarda personel eksikliği ve iş yükü nedeniyle her ne kadar çocuklarla yakından ilgilenilse de ebeveynlerinin yokluğunun hissettirdiği boşluğun yerini dolduramamaktadır. Ayrıca hali hazırda hassas bir dönem olan ergenlik çağı sorunları ailedeki iletişim sorunlarıyla birleştiğinde hem bu dönemde hem de yetişkinlik hayatında bazı sorunların ortaya çıkmasına neden olabilmektedir. Çocukların ebeveynlerine çok daha fazla ihtiyaç duyduğu bu dönemde aile içi iletişimin güçlendirilmesiyle çözülebilecek sorunlar nedeniyle kurum bakımına alınıyor olması hem çocuğu hem ailesini hem de kurumdaki personeli etkilemekte ve beraberinde birçok olumsuz deneyimi getirmektedir.

\section{Tartışma}

$\mathrm{Bu}$ araştırma geçici süre kurum deneyimi yaşamış çocukların korunma altına alınma sebeplerini ve deneyimlerini öğrenmeyi amaçlamıştır. Bu amaç doğrultusunda gerçekleştirilen derinlemesine görüşmeler sonucunda "bir cezalandırma stratejisi olarak evden kaçmak", "fiziksel şiddet", "cinsel şiddet ve aile desteğinin önemi" ve "kurum deneyimi sonrasında aileye geri dönüş" araştırmanın temel temaları olarak açığa çıkmıştır. Araştırma sonuçları, çocukların korunma altına alınma sebeplerini aile içi şiddet, ebeveyn kaybı, boşanma, ailede suç davranışı gibi sebeplerle açıklayan literatürle benzerlik ve farklılıklar arz eden noktalar taşımaktadır. Bu farklılıkların araştırma grubunun farklılığından kaynaklandığı düşünülmektedir. Başka bir deyişle, konuyla ilgili araştırmaların örneklemleri genel olarak uzun yıllar kurum deneyimi yaşamış, evlat edindirme ya da koruyucu aile modellerinden yararlanmış bireylerden oluştuğu için geçici süreyle bu deneyimi yaşamış çocukların korunma altına alınma sebepleri diğer araştırma bulgularından farklılık gösteren noktalar içermektedir. 
$\mathrm{Bu}$ anlamda ortaya çıkan en temel farklılık; ailelerin olası ihmalleri ve aile içindeki sağlıklı olmayan iletişim sebebiyle çocukların maddi ve manevi isteklerinin yerine getirilmemesi sonucunda ortaya çıkan bir cezalandırma stratejisi olarak evden kaçıştır. Günümüzde çocuğa yönelik ihmal ve istismar oranlarının ciddi boyutlarda olduğu ve çocukların bu sebeple korunmaya ihtiyacı olan çocuk durumuna düştügünü gösteren araştırmalardan (Pelendecioğlu \& Bulut, 2009; Uslu, 2019; Yolcuoğlu, 2010) farklı olarak bu tema; ailelerin çocuklarına cep telefonuna el koymak ve dışarıya çıkmasını engellemek gibi anlamlandıramadığı cezalar vermeleri, ailede kurallar, otorite ve sınırların belirgin olmaması, aşırı esnek ya da katı olması sonucunda çocukların evden kaçarak korunma altına alındıklarını göstermektedir. Bu temada özellikle ailelerin çocuklarının yakın partner ilişkisini hoş karşılamamaları ve tepkilerini ihmal ve istismar yaratacak boyutta göstermeleri, çocukların ergenlik döneminde bulunmasının getirdiği tepkisellik ve yakın partner ilişkisine yönelik ilk deneyimlerin bu yaş döneminde yaşanmasıyla birleşerek çocukların bir sorun çözümü ve cezalandırma stratejisi olarak evden kaçtıklarını göstermektedir. $\mathrm{Bu}$ doğrultuda, bu sorunlar ortaya çıkmadan önce aile ve çocuklar arasındaki sorunların tespit edilmesi, aile ve çocuklarla aile içi iletişim, yakın partner ilişkisi ve ergenlik çağına özgü sınırlara ilişkin koruyucu, önleyici ve eğitici çalışmalar gerçekleştirebilecek okul sosyal hizmetinin öneminin açığa çıktığı düşünülmektedir. Okul sosyal hizmeti kapsamında aile ziyaretleri, ebeveynlik pratiklerini geliştirmek için danışmanlık, çocukların okula devamını desteklemek, evde ve okulda uyumsuz davranışlar gösteren çocukların ihtiyacına göre şekillenen vaka çalışmaları yapılabileceği düşünülmektedir (Duman vd., 2014; Ercan, 2020; Özbesler \& Duyan, 2010; Özkan \& Selçuk, 2016).

Araştırma bağlamında ortaya çıkan bir diğer tema fiziksel şiddettir. Ailelerin çocuk yetiştirilmesi ve büyütülmesine yönelik inançları toplumların gelenek, görenek ve adetleri, sosyo-kültürel özellikleri ve kendi ailelerinde gördükleri değer, inanç, ceza ve disiplin davranışlarına göre şekillenmektedir (TekgözObuz, 2019; Yolcuoğlu, 2010). Bu çerçevede bazı ailelerin çocuğun disipline edilmesi için fiziksel ve duygusal olarak istismarı içeren davranışları gerekli gördüğü ve çoğu durumda normalleştirdikleri, dolayısıyla davranışlarının çocuk istismarı olmadığını düşündüklerini gösteren araştırmalar bulunmaktadır (Akgün Kostak \& Vatansever, 2015). Benzer şekilde, ailelerin, çocuklarına değer verdikleri ve sevdikleri halde çocuklarını sık sık fiziksel olarak cezalandırdıklarını tespit eden araştırmalar bulunmaktadır (Kükürtçü, 2011; Taş, 2017; Ünal, 2017).

Bu durum araştırma bağlamında da kendini göstermiş, çocuklar gördükleri fiziksel şiddet sonucunda evden kaçmıştır. Çocukların anlatılarında, ailelerinin uyguladıkları fiziksel şiddetin hem ebeveynlerden hem de abi, abla, dede gibi aile üyelerinden geldiği görülmektedir. Fiziksel şiddetin nedenleri incelendiğinde; çoğunlukla yakın partner ilişkisi ve okul devamsızlı̆̆ gibi aile içinde çözülebilecek sorunlar sebebiyle ailelerin şiddete başvurduğu görülmüştür. Benzer şekilde kardeş sistemlerinden gelen şiddetin kardeşlerin birbirleriyle rekabetleri ve birbirleri üzerinde kurmaya çalıştıkları otoritenin işlevsel olmayan bir şekilde gerçekleşmesiyle açıklanabileceği düşünülmektedir. Bu çerçevede okul sosyal hizmeti başta olmak üzere sosyal hizmetin yer aldığı her alanda çocuklarla ve ailelerle çocuk hakları konusunda eğitici çalışmalar 
yapmak, fiziksel şiddetin okulda ilk tespit edileceği yer olduğu göz önünde bulundurularak öğretmenlerle çalışmalar yapılması ve ailelerle fiziksel şiddetin içeriği ve her ne olursa olsun çocuğa şiddetin meşrulaştırılamayacağına yönelik eğitici öğretici çalışmaların gerçekleştirilmesine ihtiyaç bulunduğu görülmektedir.

Araştırma sonuçlarının işaret ettiği bir diğer bulgu ise çocukların cinsel şiddet deneyimleridir. Çocukların uğradıkları fiziksel, cinsel ve psikolojik şiddetin korunma altına alınma sebebi olduğu bulgusu diğer araştırmalarla paralellik göstermektedir (Beter, 2010; Turgut, 2018; Yüceer, 2012). Kadına yönelik şiddetin genelde yakın partner, eş, dost, akraba gibi kişilerden geldiğini gösteren literatüre paralel olarak (Mor Çatı, 2017), araştırma sonuçları çocukların kardeşlerinin arkadaşları, eniştesi, sevgilisi gibi kişilerin cinsel taciz ve tecavüzüne uğradığını göstermektedir. Cinsel şiddet deneyimi yaşayan kişilerin çoğunlukla travma sonrası stres bozukluğu, depresyon, anksiyete gibi psikiyatrik sorunlar yaşadıkları, özgüven eksikliği duydukları, kendini suçlama davranışı gibi bir çok sorunu (Çayır, 2019; Erol, Öztop \& Özcan, 2018; Gençtan, 2005; Yüksel \& Öncü 2016) göz önünde bulundurulduğunda, kimlik gelişimini tamamlayamamış ve cinsel istismar deneyimlerini saklayarak sosyal ve psikolojik hiçbir destek alamamış ergenlerin, aile içi sorunlarında bir çözüm olarak evden kaçması şaşırtıcı görünmemektedir. Nitekim bazı katılımcılar kuruma geliş sebeplerini ilk etapta evden kaçmaları çerçevesinde anlatsalar da görüşmenin ilerleyen safhalarında cinsel istismara uğradıkları, kendilerine inanılmadığı ya da bunu ifade etmeye korktuklarını keşfedilmiştir. Buna paralel olarak ortaya çıkan bir diğer sonuç ise, korunma altına alındıktan sonra aile destek mekanizmalarını kullanıp cinsel istismar deneyimlerini ailelerine açan katılımcıların aldıkları aile desteği ve profesyonel destek sonucunda baş etme mekanizmaları geliştirmeleri ve toplumsal yaşama uyum sağlamaya başlayabildikleridir. Dolayısıyla, çocuklarla temas eden her çalışanın ve ailelerin ihmal ve istismar konusundaki farkındalığını arttırmaya yönelik çalışmalar yapılması gereksinimi açığa çıkmaktadır.

Araştırmanın son teması kurum deneyimi sonrası aileye geri dönüştür. Bir çocuğun korunma altına alınma deneyimi başı başına olumsuz deneyimlere referans vermektedir. $\mathrm{Bu}$ bağlamda araştırma kapsamında kurum bakımında olunan süre içerisinde sorunların daha da çeşitlendiği, çocuğun ve ailenin hayatına yeni bir olumsuz deneyim eklendiği söylenebilmektedir. Bir cezalandırma stratejisi olarak evden kaçan ve kurum bakımına alınan çocukların pişmanlık yaşadığı ve tekrar ailelerine dönmek istedikleri görülmektedir. Hem çocuğu hem aileyi etkileyen ve örseleyen bu durumun aynı zamanda meslek elemanlarının iş yükünü arttırdığı, bu süreç içerisinde bireysel görüşmeye ve desteğe ihtiyaç duyan diğer korunmaya muhtaç çocukların mağduriyet yaşayabilecekleri, kuruluşların ve meslek elemanlarının etkili ve verimli hizmet verme kapasitelerini etkileyebileceği düşünülmektedir. Şüphesiz ki korunma talep eden, evden kaçan ya da ihmal ya da istismara uğradığını düşünen her çocuğun devlet korumasından yararlanması temel bir çocuk hakkıdır ve her çocuk bu haktan yararlanmalıdır. Ancak aynı zamanda "babam bana cep telefonu almadı" ya da "sevgilimle görüşmek istiyorum" gibi aile danışmanlığı çerçevesinde çözülebilecek korunma altına alınma sebeplerinin ortaya çıkmaması adına okullardan başlayarak, ailelere, öğretmenlere ve çocuklara yönelik eğitici öğretici çalışmalar yapılması, hem çocukların kurum deneyiminden 
kaynaklanabilecek travmatik yaşantılarının önlenmesi hem de sosyal hizmet kurum ve kuruluşlarının etkili ve verimli hizmet süreçlerini sürdürebilmesi açısından önemli görülmektedir.

\section{Sonuç ve Öneriler}

$\mathrm{Bu}$ araştırma, 13-18 yaş aralığında geçici süreyle kurum deneyimi yaşamış çocukların korunma altına alınma sebepleri ve deneyimlerini çocukların kendi anlatıları üzerinden öğrenmeyi amaçlamıştır. Bu amaç doğrultusunda kartopu yöntemiyle on çocuğa ulaşılmış ve derinlemesine görüşmeler yapılmıştır. Bir cezalandırma stratejisi olarak evden kaçış, fiziksel şiddet, cinsel şiddet ve aile desteğinin önemi ve kurum deneyimi sonrası aileye geri dönüş araştırmanın dört temel teması olarak keşfedilmiştir. Bu sebeplere yönelik koruyucu önleyici çalışmaların başında ise okul sosyal hizmeti gelmektedir.

Türkiye'nin bazı illerinde proje olarak yürütülen okul sosyal hizmeti kapsamında, çocuklara, ailelere ve öğretmenler başta olmak üzere çalışanlara ihmal, istismar, aile içi iletişim ve çocuk hakları konusunda farkındalık artırıcı çalışmalar yapılması ve eğitici-öğretici faaliyetler gerçekleştirilmesi gerektiği düşünülmektedir. Çocuklara yönelik tasarlanacak çalışmaların çocuk haklarını içermesi aynı zamanda aile içerisinde kurallar, roller ve sınırlar olduğu ve bu kurallar, roller ve sınırların çocuk haklarını ihlal ettiği noktada kabul edilemeyeceğinin öğretilmesi gerekmektedir. Benzer şekilde, aile içi geçimsizlik, ebeveyn kaybı boşanma gibi sebeplerin çocukların korunma altına alınmasının başlıca sebepleri olduğu göz önünde bulundurularak, okulda varsa psikolojik danışman ve rehber öğretmeni ve sosyal hizmet uzmanının ortak çalışmalarıyla aile ve çocuk takip edilerek ailevi sorunlar yaşayan çocuklara danışmanlık sunulmalıdır. Benzer şekilde, okul terkinin önlenmesi ve çocukların takip edilmesi bu kapsamda yapılabilecek çalışmalardandır.

Çocuk haklarına yönelik eğitici öğretici çalışmalar aynı zamanda ailelerle de gerçekleşmeli, aile içi sorunlarda, çatışma çözümünde ya da ebeveyn otoritesinin kurulma sürecinde şiddetin herhangi bir türünün kabul edilemeyeceği ve şiddetin bir iki defalık ya da büyüğü ve küçügü olmayacağının öğretilmesi gerekmektedir. Ailelere, ergenin gelişimsel sorunları nedeniyle yaşanan problemlerle baş etme mekanizmalarının artırılması ve ebeveynlik kapasitelerinin güçlendirilmesi çalışmaları da yapılmalıdır. Bununla birlikte, ailelerle ergenlik döneminin özellikleri ve yakın ilişkiler hakkında konuşulması gerektiği, ailelerin onaylamadıkları ilişkileri neden onaylamadıklarını çocuklarıyla paylaşması ve bunu nasıl yapabileceklerine yönelik danışmanlık verilmelidir.

Çocukların korunma altına alınma sebeplerinin ilk olarak gözlemlenebileceği yer okul olmaktadır, dolayısıyla koruyucu önleyici çalışmaların okulda başlaması gerektiği düşünülmektedir. Ancak koruyucu önleyici çalışmaların yetmediği noktada sosyal hizmet kurum ve kuruluşlarında çalışan meslek elemanlarına önemli görevler düşmektedir. Dolayısıyla öncelikle bu kurum ve kuruluşlarda çalışan meslek elemanı sayısı artırılarak meslek elemanlarının iş yükünün hafifletilmesi gerektiği, bu doğrultuda meslek elemanlarının çocuklara daha etkili ve verimli hizmet sunabilecekleri düşünülmektedir. Bunun yanında meslek 
elemanlarının eğitici öğretici rolü dahilinde bu kurum ve kuruluşlarda çalışan diğer personellerin ihmal ve istismar konusundaki farkındalığını arttırmaya yönelik çalışmalar yapması gerektiği düşünülmektedir.

Bununla birlikte sevgi evlerinin ve çocuk evlerinin sayısının arttırılma politikasının çocuk koruma alanında önemli gelişmeler olduğu ancak çocukların kurum deneyimi sonrası olumsuz yaşantılar ve sorunlar yaşamasını önlemek adına bu kuruluşların niteliğinin ve niceliğinin arttırılması, çocukları kurum deneyimi sonrasında izleyen takip mekanizmalarının geliştirilmesi gerektiği düşünülmektedir.

Son olarak, çocuk korunmada sorumlu olan kurumların sadece okul ya da sosyal hizmet kuruluşları olmadığını, başta çocuk refahı alanında çalışan her kişi olmak üzere sorumluluğun tüm toplumun olduğunu belirtmek gerekir. Bu doğrultuda çocuğa yönelik şiddet, çocuk işçiliği, erken yaşta ve zorla evlilikler başta olmak üzere çocuk haklarını ihlal eden her türlü eylem için kamu, sivil toplum, medya iş birliği içerisinde eğitici öğretici çalışmaların yapılması ve topluma ihbar mekanizmalarının öğretilmesi gerektiği düşünülmektedir. Bununla birlikte korunmaya ihtiyacı olan çocukların kurum bakımı öncesi, sırası ve sonrasındaki deneyimlerini bir bütün olarak ele alan nitel ve nicel araştırmaların, bu çocuklarla çalışma konusunda eğitimi olan ve etik konuları göz önünde bulunduran disiplinlerce ele alınması ve alandaki çalışmaların niteliğinin ve niceliğinin artırılması önerilmektedir.

\section{Araștırmacıların Katkı Oranı}

Araştırmada birinci ve üçüncü yazar makalenin yazımından (\%60), ikinci yazar veri oluşturulması ve toplanması süreçlerinden $(\% 40)$ sorumludur.

\section{Destek ve Teșekkür Beyanı}

Araştırmada herhangi bir destekten yararlanmamıştır. Araştırmacılar araştırmaya katılan tüm katılımcılara teşekkür etmektedir.

\section{Çatışma Beyanı}

Araştırmacılar arasında çıkar çatışması bulunmamaktadır 


\section{Kaynaklar}

Aile ve Sosyal Hizmetler Bakanlığı, Çocuk Hizmetleri Genel Müdürlüğü (2021, Nisan 23). Özgür ansiklopedi wiki içinde. 24 Nisan 2021 tarihinde http://cocukhizmetleri.aile.gov.tr/uygulamalar/cocuk-destek-merkezleri adresinden erişildi.

Akgün Kostak, M. \& Vatansever, C. (2015). Sağlık Bilimleri Fakültesi Öğrencilerinin Çocuk İstismarı ve İhmali İle İlgili Görüş ve Düşünceleri. $H S P, 2(1), 1-11$.

Aşık, E. (2006). Yetiştirme yurdunda kalan gençlerin ergenlik sorunları ve baş etmeleri. (Yayınlanmamış yüksek lisans tezi). Abant İzzet Baysal Üniversitesi Sağlı Bilimleri Enstitüsü, Bolu.

Baker, C. (2017). Care leavers' views their transition to adulthood: A rapid review of the evidence. Coram Voice.

Barış, İ. \& Taylan, H. H. (2020). Sosyal hizmet ve toplum, Korunma ihtiyacındaki çocuklar, sosyal hizmetin temel konuları içinde (9-31). Malkoç, E.S., Grafiker Yayınları.

Beter, Ö. (2010). Türkiye ve Ingiltere'de çocuk koruma sistemleri. (Yayımlanmamış doktora tezi). Hacettepe Üniversitesi Sosyal Bilimler Enstitüsü, Ankara.

Bethell, C. D., Newacheck, P., Hawes, E. \& Halfon, N. (2014). Adverse childhood experiences: assessing the impact on health and school engagement and the mitigating role of resilience. Health Affairs, 33(12), 2106-2115.

Boduroğlu, G. (2016). Kurum bakımından ayrılan bireylerin yaşamın düzenlenmesi ve uyum sürecinde karşılaştığı sorunlar ve sosyal destek kaynakları. (Yüksek lisans tezi). Ankara Yıldırım Beyazıt Üniversitesi Sağlık Bilimleri Enstitüsü, Ankara.

Cebe, F. (2005). Sosyal Hizmetler ve Çocuk Esirgeme Kurumu yetiştirme yurtlarında barınan çocukların "benlik saygısı", “depresyon", "kaygı” skorlarının ailesi yanında kalan çocuklarla karşılaş̧tırılması. (Yüksek lisans tezi). İstanbul Üniversitesi Adli Tıp Enstitüsü, İstanbul.

Çayır, H. (2019). Kurum bakımı geçmişi olan bireylerin kurum bakımı deneyimleri ve etiketlenme durumları. (Yüksek Lisans Tezi). Yalova Üniversitesi Sosyal Bilimler Enstitüsü, Yalova.

Çocuk Koruma Kanunu. (ÇKK). 5395 Sayılı Kanun. (2005, 3 Temmuz). Resmi Gazete (Sayı: 25876). Erişim adresi: http://oges.meb.gov.tr/doc2012/5395_SAYILI_COCUK_KORUMA_KANUNU.pdf

Dutta, S. (2017). Life after leaving care: Experiences of young Indian girls. Children and Youth Services Review, 73, 266-273.

Ercan, F. Z. (2020). Okul Sosyal Hizmeti Bağlamında Suriyeli Çocukların Eğitim Sorunları. Erişim adresi: https://www.cizgikitabevi.com/kitap/1090-okul-sosyal-hizmeti-baglaminda-suriyeli-cocuklarin-egitimsorunlari

Erkan, G. (1995). Korunmaya muhtaç çocuklar: çocuk yuvalarinda bir araştırma. TC Başbakanlık Gençlik Spor ve Genel Müdürlüğü Yayınları.

Gallwey, S. (2013). The relationship between attachment and resilience in foster care alumni. Erişim adresi: https://search.proquest.com/docview/1314577275?accountid=16382 /Erişim tarihi: 15.04.2021.

Geçtan, E. (2005). Psikanaliz ve sonrası. Metis Yayınları. 
Güven S. \& Bilir, M. (2020). 23 Nisan Ulusal Egemenlik ve Çocuk Bayramı 100. Yıl Özel Çocuk Bülteni. Erişim adresi: https://www.ailevecalisma.gov.tr/chgm/sayfalar/23-nisan-cocuk-bulteni/Erişim tarihi: 23.04.2021.

Holt, S., Buckley, H., \& Whelan, S. (2008). The impact of exposure to domestic violence on children and young people: A review of the literature. Child Abuse \& Neglect, 32(8), 797-810.

Kutlu, M. (1998). Yetiştirme yurdu öğrencilerinin özsaygı düzeylerinin incelenmesi. Eğitim ve Bilim, 22(10), 25-30.

Kükürtçü, S. (2011). 5-6 yaş çocuklarının ailelerinin ve öğretmenlerinin kullandıkları disiplin yöntemlerinin çocuk hakları ile ilişsisinin incelenmesi. (Yüksek lisans tezi). Hacettepe Üniversitesi Sosyal Bilimler Enstitüsü, Ankara.

Lök, N, Başoğul, C. \& Öncel S. (2016). Aile içi şiddetin çocuk üzerindeki etkileri ve psikososyal desteğin önemi. Psikiyatride Güncel Yaklaşımlar, 8(2), 156-161. [Electronic Journal] https://dergipark.org.tr/tr/pub/pgy/issue/11172/133540

Melkman, E.P. \& Benbenishty, R. (2018). Social support networks of care leavers: mediating between childhoodadversity and adult functioning. Children and Youth Services Review, 86, 178-187.

Mor Çatı Kadın Sı̆̆ınağı Vakfı. (2017). Mor Çatı Deneyimi Kadına Yönelik Şiddete Dair Neler Anlatıyor?. https://www.morcati.org.tr/attachments/article/466/kadina-yonelik-siddet-degerlendirme-raporu.pdf

Obuz, A. T. (2019). Suça sürüklenen ve hakkında danışmanlık tedbir kararı verilen çocukların suça sürüklenme nedenleri: nitel bir çalışma. Uluslararası Sosyal Araştırmalar Dergisi, 12(67), 630-641.

Oral, R., Ramirez, M., Coohey, C., Nakada, S., Walz, A., Kuntz, A. \& Peek-Asa, C. (2016). Adverse childhood experiences and trauma informed care: the future of health care. Pediatric Research, 79(1), 227-233.

Özkan, Y. \& Selçik, O. (2016). Okul sosyal hizmetinin okul erken terki üzerine potansiyel etkisi. Journal of International Social Research, 9(43), 431-437.

Pelendecioğlu, B. \& Bulut, S. (2009). Çocuğa yönelik aile içi fiziksel istismar. Abant İzzet Baysal Üniversitesi Dergisi, $9(1), 49-62$

Sarıaltın, D. M. (2017). Kurum bakımındaki çocuklara ilişskin sistemin sosyal refah çalışanları gözüyle değerlendirilmesi. (Yayımlanmamış yüksek lisans tezi). Hacettepe Üniversitesi Sosyal Bilimler Enstitüsü, Ankara.

Sosyal Hizmetler ve Çocuk Esirgeme Kurumu (SHÇEK) Kanunu. 2828 Say1lı Kanun. (1983, 27 Mayıs). Resmi Gazete (Sayı: 18059). Erişim adresi: https://www.mevzuat.gov.tr/anasayfa/MevzuatFihristDetayIframe?MevzuatTur=7\&MevzuatNo=19778\&M evzuatTertip $=5$

Şimşek, Z., Erol, N., Öztop, D. \& Özcan, Ö. Ö. (2018). Kurum bakımındaki çocuk ve ergenlerde davranış ve duygusal sorunların epidemiyolojisi ulusal örneklemde karşılaştırmalı bir araştırma. Türk Psikiyatri Dergisi, 19(3), 235- 246.

Tuncer, B. \& Erdoğan, T. (2018). Korunmaya muhtaç çocuklar ve korunmaya muhtaç çocuklara sağlanan bakım yöntemleri. Uluslararası Bilimsel Araştırmalar Dergisi (Ibad), 3(2), 515-527. 
Turgut A. Ş. \& Özkan, Y. (2019). Kurum bakımından ayrılmış bireylerin sosyo-demografik özellikleri ile kurum bakımı sonrası yaşadıkları sorunlar arasındaki ilişkinin incelenmesi. Türkiye Sosyal Araştırmalar Dergisi, 24(3), 748-763.

Turgut, A. Ş. (2018). Türkiye'deki kurum bakımında büyümüs bireylerin psikolojik dayanıklllk (yılmazlık) düzeylerinin incelenmesi. (Yüksek lisans tezi). Hacettepe Üniversitesi Sosyal Bilimler Enstitüsü, Ankara.

UK Department of Education (2018). Children in Need of Help and Protection. Erişim adresi: https://assets.publishing.service.gov.uk/government/uploads/system/uploads/attachment_data/file/690999/C hildren_in_Need of help_and_protection_Data_and_analysis.pdf

Uluğtekin, S. (1993). Çocuk yuvaları: uygulamanın son araştırmalar ışı̆̆ında değerlendirilmesi. Hacettepe Üniversitesi Sosyal Hizmetler Yüksekokulu Dergisi, 11(1-2-3), 35-55.

Uslu, G. (2019). Çocuk ihmal ve istismarı alanında çalışan profesyonellerin sunulan hizmetlere iliş̧kin değerlendirilmesi. (Yüksek lisans tezi). Başkent Üniversitesi Sosyal Bilimler Enstitüsü, Ankara.

Ünal, H. B. (2017). Ebeveyn çocuk ihmal ve istismarı farkındalık ölçeğinin geliştirilmesi ve uygulanması. (Yüksek lisans tezi). Hacettepe Üniversitesi Eğitim Bilimleri Enstitüsü, Ankara.

Varol, B. (2017). Kurum bakımı deneyimi olan yetişkinlerin iş yaşamına uyumları. (Yayımlanmamış yüksek lisans tezi). Yıldırım Beyazıt Üniversitesi Sağlı Bilimleri Enstitüsü, Ankara.

Yolcuoğlu, İ. G. (2009). Türkiye'de çocuk koruma sisteminin genel olarak değerlendirilmesi. Aile ve Toplum, 11(18), 43-57.

Yolcuoğlu, İ. G. (2010). Çocukların ihmal-istismara uğramasında aile ve çocuklara yönelik risk faktörleri ve sosyal hizmet müdahalesi. Toplum ve Sosyal Hizmet, 21(1), 73-83.

Yüceer, T. (2012). Kurum bakımı deneyimi olan bireylerin evlilik uyumları. (Yüksek lisans tezi). Hacettepe Üniversitesi Sosyal Bilimler Enstitüsü, Ankara.

Yüksel, Z. (2016). Kurum bakımında kalmış yetişkinlerde bağlanma biçimleri ve ruhsal sorunlar. (Yüksek lisans tezi). Ankara Üniversitesi Sağlık Bilimleri Enstitüsü, Ankara. 


\section{Ek-1}

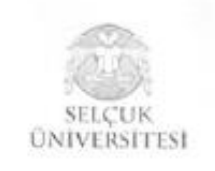

Sayl:2020/06-EK

\author{
T.C. \\ SELCUK ÜNIVERSITESI \\ SAǴLIK BILIMLERI FAKÜLTESI \\ Girişimsel Olmayan Klinik Araştımalar Etik Kurulu
}

\section{ARAȘTIRMA PROJESI DEǴERLENDIRME} FORMU

$\begin{array}{ll}\text { Toplant tarihi: } & 06 / 07 / 2020 \\ \text { Toplant no: } & 06-\mathrm{EK} \\ \text { Proje no: } & 638 \\ \text { Karar no: } & 2020 / 638\end{array}$

Selçuk Üniversitesi Sağlık Bilimleri Fakulltesi Sosyal Hizmet Bölüma Doç.Dr. Serap DAȘBAȘ’n "Çocuk Hakları Eğitimi Verilmeli Ama Nasıl? Gümümüz Kortunmaya Muhtą̧ Cocukların Değisen Ihmal ve Istismar Algıst" başlıklı çahışmast görüşüldü. Çalışma, etik açıdan uygun bulunmuștur.

Prof. Dr. Didem (Bay ônin (Ban)

Doç. Dr. Nur FEYZAL KESEN (Ǔye) KATILMADI

Dr. Ör. Oyesi Sh hel FIL IZ (Oye)

Dr. Ögr. Üyesi Özden KATILMADI

Arş Gür Dr. Cengif ÇELIK (Ôye)<smiles>C1CC2CC3CC1CC23</smiles>

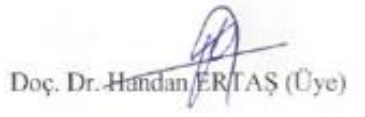

Dr. Ögr. Oyesifgülperi DEMIR (Ôye)

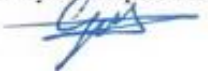

Dr. Ör. Oyesi Bihter AKIN(Oye) KATILMADI

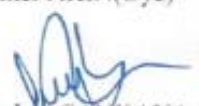

SGUK BLUMLPRIAKOLTES|

Tarih: 06/07/2020 